\title{
Randomised controlled trial of lymphoblastoid interferon alfa in Europid men with chronic hepatitis B virus infection
}

\author{
M Gary Brook, Gerald Chan, Ivy Yap, Peter Karayiannis, Andrew M L Lever, Meron Jacyna, \\ Janice Main, Howard C Thomas
}

\begin{abstract}
Objective-To confirm the findings of pilot studies that interferon alfa is an effective treatment of Europid men with chronic hepatitis B virus infection.

Design-Randomised controlled trial of three months' treatment with interferon alfa followed by 12 months of observation.

Setting-Outpatient clinic of a tertiary referral centre.

Patients - 37 Treated men (six anti-HIV positive) and 34 untreated men (nine anti-HIV positive) who met the criteria for the trial. Four controls failed to complete follow up.

Interventions - The treated group received subcutaneous injections of 5-10 MU interferon alfa/m² daily for five days, then $10 \mathrm{MU} / \mathrm{m}^{2}$ thrice weekly for 11 weeks. Follow up continued at monthly intervals for 12 months. Untreated controls were monitored over the same period.
\end{abstract}

Main outcome measure-Hepatitis B e antigen and hepatitis B virus DNA state after 15 months of observation.

Results -12 Of the 37 treated patients cleared hepatitis B e antigen and hepatitis B virus DNA, whereas only one of 30 untreated controls seroconverted over the same period - an increased response rate of $29 \%$ ( $95 \%$ confidence interval $13 \%$ to $45 \%$ ). The life table estimate of response at 15 months was $35 \%$ in treated patients, an increase of $32 \%$ above controls ( $95 \%$ confidence interval $16 \%$ to $48 \%$ ). The response rates in groups by predictive pretreatment variables were 12 of 31 anti-HIV negative patients (excess response $34 \% ; 95 \%$ confidence interval $14 \%$ to $54 \%), 12$ of 26 with chronic active hepatitis before treatment (excess response $46 \% ; 27 \%$ to $65 \%$ ), and 12 of 21 with a pretreatment serum aspartate aminotransferase activity $>70$ IU/1 (excess response $\mathbf{4 6 \%}$; $16 \%$ to $76 \%$ ). The combination of these factors predicted response with a sensitivity of $100 \%$ and a specificity of $80 \%$. Four of the 12 responders, who had all been infected for less than two years, also lost hepatitis B surface antigen. Treatment was well tolerated.

Conclusions-Interferon alfa is effective in the treatment of a proportion of Europid men with chronic hepatitis B virus infection, who might be identified before treatment. Additional strategies are required to improve the rate of response.

\section{Introduction}

Most of the world's 200 million hepatitis B carriers are found in Far Eastern countries, of whom the majority were infected at birth by vertical transmission of the virus. ${ }^{1+4}$ Carriage of the hepatitis B virus is found in $0 \cdot 1-0 \cdot 2 \%$ of the population of the United Kingdom, of whom most have been infected as a result of sexual contact, drug abuse, and the use of contaminated blood products (horizontal transmission). 25 Long term follow up of patients with chronic hepatitis B virus infection in the United Kingdom and the Far East have so far found that one fifth to half of the deaths were due to cirrhosis or hepatocellular carcinoma. ${ }^{6-8}$ Vertically acquired disease responds poorly to antiviral measures, ${ }^{10}$ but several small studies have established the success of interferon alfa in infections acquired in adulthood..$^{11 \cdot 13}$ This larger trial was initiated to try to confirm these preliminary results and also to identify factors that might be used to predict which group of patients responds to treatment.

\section{Patients and methods}

A consecutive series of 71 Europid men who had definite hepatitis B e antigen and hepatitis B virus DNA positive, anti-delta negative hepatitis $B$ infection of greater than six months' duration were admitted to the trial (table I). All gave written informed consent. The protocol was approved by the hospital's clinical trials ethics committee and carried out under a clinical trials licence issued by the Department of Health and Social Security.

Qualifying patients were stratified by ethnic origin (northern European versus Mediterranean), sexual preference (homosexual versus heterosexual), and histological findings in the liver (chronic active hepatitis

TABLE I-Inclusion and exclusion criteria used in trial

\begin{tabular}{lc}
\hline Criteria for inclusion in trial & Criteria for exclusion from trial \\
\hline Age 18-65 & Continuing drug abuse \\
Male Europid & Antiviral or immunosuppressive \\
Documented hepatitis B virus & treatment within past six months \\
infection (positive for hepatitis & Coexistent chronic illness including \\
B e antigen and hepatitis B virus & liver disease unrelated to hepatitis B \\
DNA) for over six months & virus infection \\
Liver biopsy within six months & Karnofsky test performance $<80 \%$ \\
of entry showing chronic & \\
hepatitis & \\
Ability to comply with trial & \\
requirements & \\
\hline
\end{tabular}

versus chronic persistent hepatitis). They were then randomly assigned to receive interferon alfa (treated group; $n=37$ ) or no treatment (controls; $n=34$ ). Initial daily subcutaneous injections of $5 \mathrm{MU} / \mathrm{m}^{2}$ for three days were followed by $10 \mathrm{MU} / \mathrm{m}^{2}$ for a further two days, then $10 \mathrm{MU} / \mathrm{m}^{2}$ thrice weekly for 11 weeks. Most patients injected the drug themselves in the late evening.

Each patient was reviewed daily for the first five days, weekly during the next 11 weeks, and monthly for one year after treatment. Untreated controls were seen monthly for 15 months. At each visit blood was taken for routine haematological studies, estimation of prothrombin time, liver function tests, including assessment of aspartate aminotransferase activity, hepatitis B serology, hepatitis B virus DNA state, presence of anti-interferon antibodies, and HIV serology as appropriate. At the end of treatment patients completed a questionnaire on the severity of side effects (graded mild, moderate, or severe) and their tolerance of treatment. On completing follow up patients were requested to have a further liver biopsy, after which untreated controls were offered interferon.
Correspondence to: Dr Brook.
BMJ VOLUME 299

9 SEPTEMBER 1989 
SEROLOGICAL METHODS

Hepatitis B surface antigen was measured by an in house monoclonal antibody based radioimmunoassay ${ }^{1+}$ and hepatitis $\mathrm{B}$ e antigen, antibody to e antigen, and antibody to surface antigen by commercial radioimmunoassays (Abbott Laboratories, Chicago). Serum hepatitis B virus DNA was measured by using phosphorus-32 labelled cloned DNA in a molecular hybridisation technique. ${ }^{15}$ Anti-HIV was detected by means of an enzyme linked immunosorbent assay (ELISA; Wellcome Laboratories, Beckenham, Kent). HIV p24 antigen and anti-p24 were also measured by ELISA (Abbott Diagnostic Products, WiesbadenDelkenheim West Germany).

Anti-interferon antibody was detected by means of a biological method in which serum containing antibody inhibits the cytoprotective effects of interferon alfa when assayed with V3 monkey kidney cells (Wellcome Laboratories, Beckenham, Kent) and challenged with Semliki Forest virus. In brief, six serial $\log _{10} 0 \cdot 5$ dilutions containing $10^{35}$ to $10 \mathrm{IU}$ interferon alfa per litre were mixed with equal volumes of $1 / 10$ dilutions of test serum or suitably diluted positive or negative control serum in maintenance medium (minimum essential medium with $0 \cdot 2 \%$ fetal calf serum) and 150 $\mu \mathrm{l}$ added to duplicate microtitre wells containing V3 cell monolayers. After overnight incubation at $37^{\circ} \mathrm{C}$ the cells were challenged with virus and reincubated for a further 48 hours. A positive result was one in which cytoprotection was seen in one whole well fewer than the negative control and was confirmed in duplicate assays. The cut off was 3 standard deviations from the mean in 50 control patients. This would detect antibody titres per millilitre of $1 / 10$ diluted serum with the capability of neutralising interferon concentrations of at least $30 \times 10^{3} \mathrm{IU} / 1$.

$\beta_{2}$ Microglobulin was measured retrospectively by radioimmunoassay (Pharmacia Diagnostics, Uppsala, Sweden) in serum samples taken at monthly intervals.

\section{HISTOPATHOLOGICAL METHODS}

Liver biopsy samples taken within six months before and exactly 12 months after treatment were assessed by experienced histopathologists. Mild chronic active hepatitis was diagnosed in preference to chronic persistent hepatitis in the presence of piecemeal necrosis. Active cirrhosis indicated samples with nodule formation and a definite inflammatory infiltrate.

\section{STATISTICAL METHODS}

The sample size required was calculated from the results of pilot studies, in which a response rate of $40 \%$ and a natural serocoversion rate of $5 \%$ were observed. Thirty two patients were required in each group to give $80 \%$ power to the trial at the 0.05 level of significance.

The significance of difference in the proportions of patients losing hepatitis B e antigen and hepatitis B

TABLE II-Characteristics of patients

\begin{tabular}{lcc}
\hline & Treated group & Controls \\
\hline No & 37 & 34 \\
Mean age (years) range) & $36,18-56)$ & $34(21-61)$ \\
No homosexual & 21 & 20 \\
No heterosexual & 16 & 14 \\
$\begin{array}{l}\text { Duration of hepatitis (months) } \\
\quad \text { (range) }\end{array}$ & $32(6-67)$ & $18(6-60)$ \\
$\begin{array}{l}\text { Nowith history of acute hepatitis } \\
\text { Median aspartate }\end{array}$ & 13 & 5 \\
$\quad$ aminotransferase (IU/l) (range) & $79(23-460)$ & $57(25-420)$ \\
$\begin{array}{l}\text { Median hepatitis B virus DNA } \\
\text { (ng/l) (range) }\end{array}$ & $2688(108->2880)$ & $2880(6->2880)$ \\
No anti-HIV positive & 6 & 9 \\
Nowith chronic active hepatitis & 26 & 27 \\
No with chronic persistent & 11 & 7 \\
$\quad$ hepatitis & 27 & 28 \\
No Northern European & 10 & 6 \\
No Mediterranean &
\end{tabular}

TABI.: III-Hepatitis B virus state at end of 15 months' follow up

\begin{tabular}{|c|c|c|c|c|c|c|c|c|}
\hline & & & \multicolumn{3}{|c|}{$\begin{array}{l}\text { Trealed group } \\
\qquad \mathrm{n}=37\end{array}$} & \multicolumn{3}{|c|}{$\begin{array}{l}\text { Controls } \\
\mathrm{n}=30^{\star}\end{array}$} \\
\hline \multicolumn{3}{|c|}{$\begin{array}{l}\text { No positive for hepatitis } B \text { c antigen } \\
\text { and hepatitis } B \text { virus } 1 \mathrm{NA}\end{array}$} & \multicolumn{3}{|c|}{25} & \multicolumn{3}{|c|}{29} \\
\hline \multicolumn{9}{|c|}{ No negative for hepatitis } \\
\hline $\begin{array}{l}\text { Be antigen an } \\
\text { virus DNA }\end{array}$ & itis & & & 12 & & \multicolumn{3}{|c|}{1} \\
\hline \multirow{2}{*}{\multicolumn{3}{|c|}{$\begin{array}{l}\text { No negative for hepatitis B surface } \\
\text { antigen }\end{array}$}} & & & & \multirow{2}{*}{\multicolumn{3}{|c|}{1}} \\
\hline & & & & 4 & & & & \\
\hline \multicolumn{9}{|c|}{ * Four controls failed to complete follow up. } \\
\hline \multicolumn{9}{|c|}{$\begin{array}{l}\text { TABLE IV - Life table estimates of response. Figures are percentages } \\
\text { (SE in parentheses) }\end{array}$} \\
\hline & \multicolumn{8}{|c|}{ Follow up months } \\
\hline & 0 & 1 & 4 & 5 & 6 & 8 & 9 & 15 \\
\hline $\begin{array}{l}\text { Treated group } \\
(\mathrm{n}=34)\end{array}$ & () & 3 & 14 & 20 & 23 & 24 & 32 & $35(6)$ \\
\hline Controls $(n=34)$ & 0 & 0 & 3 & 3 & 3 & 3 & 3 & $3(0 \cdot 5)$ \\
\hline
\end{tabular}

virus DNA in each group was measured by $\chi^{2}$ test with Yates's correction and 95\% confidence intervals calculated. Life table estimates of response rates were calculated with the Kaplan-Meier method and the differences between treated and control patients assessed by the log rank test. The strength of association between pretreatment variables and response and the independence of predictive variables were assessed by $\gamma^{2}$ test with Yates's correction or Fisher's exact test for dichotomous variables and Student's $t$ test for continuous variables. Values of aspartate aminotransferase activity were transformed logarithmically before analysis. Changes in $\beta_{2}$ microglobulin concentration were assessed by the Wilcoxon rank sum test for comparing two populations.

\section{Results}

The only difference in characteristics of patients between the treated group and untreated controls was the shorter estimated mean duration of disease in the controls (table II). Only five of the controls, however, gave a definite history of acute hepatitis at onset, so that the estimation of duration of disease were unreliable. Four of the 34 controls failed to complete follow up and are therefore excluded from the end point analysis but are included in the life table estimates.

Of the 37 patients who received interferon alfa, 12 became persistently negative for hepatitis $\mathrm{B}$ e antigen and hepatitis B virus DNA by 15 months of follow up. By contrast seroconversion occurred in only one of 30 controls followed up over the same period, giving an excess response of $29 \%$ in the treated group $\left(\chi^{2}=6.9\right.$; $\mathrm{p}<0.01 ; 95 \%$ confidence interval $13 \%$ to $45 \%$; table III). The estimated response rate by life table analysis at 15 months of follow up was $35 \%$-that is, $32 \%$ greater than in controls $\left(\psi^{2}=9.4 ; \mathrm{p}<0.005 ; 95 \%\right.$ confidence interval $16 \%$ to $48 \%$; table IV). Loss of hepatitis B surface antigen occurred in four of the 12 responders to interferon alfa and in the single control who seroconverted.

All responders were anti-HIV negative, giving a response rate of $12 / 31$ in this group as compared with $1 / 20$ among controls (excess response $34 \% ; \gamma^{2}=5 \cdot 9$; $\mathrm{p}<0.02 ; 95 \%$ confidence interval $14 \%$ to $54 \%$ ). Similarly, all responders had chronic active hepatitis on pretreatment liver biopsy, so that the response rate in patients positive for this variable was 12/26 $v 0 / 24$ controls $\left(\gamma^{\prime}=12 \cdot 2 ; \mathrm{p}<0.005 ; 95 \%\right.$ confidence interval $27 \%$ to $65 \%$ ). The response rate of $12 / 21$ in treated patients whose pretreatment serum aspartate aminotransferase activity was $>70 \mathrm{IU} / 1$ was $46 \%$ higher than in similar controls $\left(\chi^{2}=3 \cdot 8 ; p=0.05 ; 95 \%\right.$ confidence 
interval $16 \%$ to $76 \%$ ). Two anti-HIV positive controls were negative for hepatitis B virus DNA but not hepatitis B e antigen at the end of follow up, but became positive for both markers subsequently. One treated patient was negative for hepatitis B virus DNA but not hepatitis $B$ e antigen when last seen two months after treatment. Only six of the 12 responders acquired antibody to e antigen and one of the four patients losing hepatitis B surface antigen acquired antibody to this antigen.

The mean aspartate aminotransferase activities and hepatitis $\mathrm{B}$ virus DNA concentrations in 10 patients whose response showed a temporal relation to treatment were compared with those in non-responders and controls (fig 1). The fall in hepatitis B virus DNA concentrations in responders was of a greater magnitude and more sustained than that in non-responders, who quickly regained pretreatment values after stopping treatment. Though most treated patients showed a rise in aspartate aminotransferase activity beginning after four to six weeks of treatment, the peak activity at eight weeks was higher in responders (274 IU/l) than in nonresponders (119 IU/1).
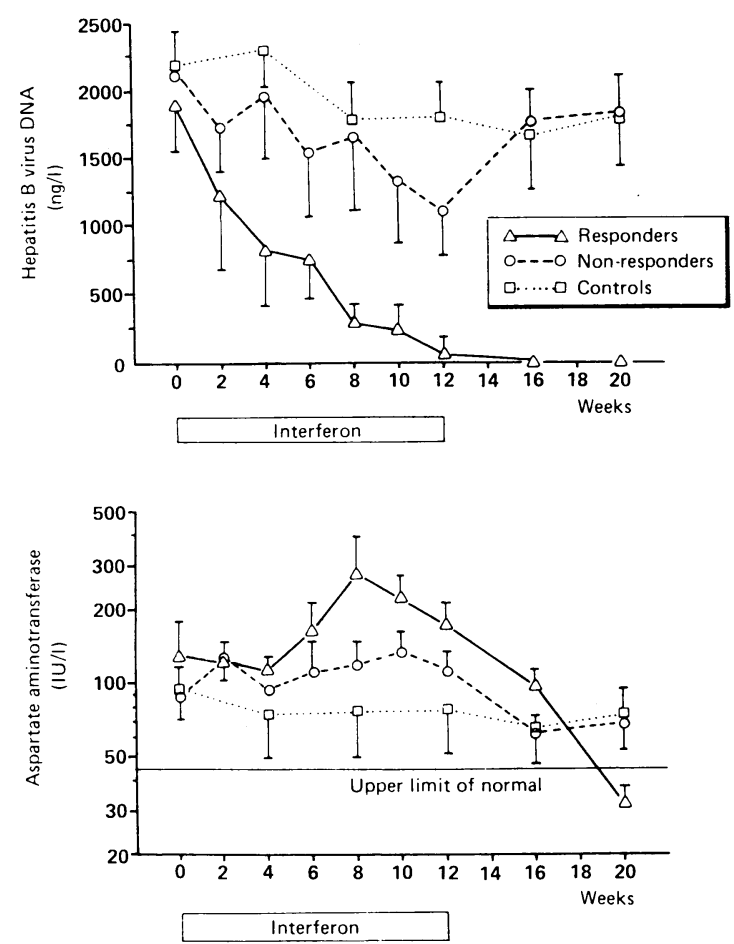

FIG 1 -Course of mean hepatitis $B$ virus DNA concentrations and mean aspartate aminotransferase activities in relation to treatment. Bars are SE

In all treatment responders the aspartate aminotransferase activity became and remained normal concurrent with the loss of hepatitis B e antigen up to three months after the hepatitis B virus DNA concentration became zero. Loss of hepatitis $B$ surface antigen occurred one to three months later.

Predicitive value of pretreatment variables-Age, sexual orientation, duration of disease, history of acute hepatitis, ethnic origin (northern European versus Mediterranean), and hepatitis B virus DNA state were not significantly associated with response. Chronic active hepatitis in pretreatment liver biopsy samples $\left(\chi^{\prime}=5 \cdot 6 ; \mathrm{p}<0 \cdot 02\right)$, a high serum aspartate aminotransferase activity $(t=2 \cdot 6 ; \mathrm{p}<0 \cdot 02)$, and the absence of anti-HIV $\left(\chi^{2}=5 \cdot 3 ; p<0 \cdot 05\right)$ were significantly related to an increased likelihood of response on univariate analysis (table V). Anti-HIV state was the only independent predictive factor. The combination of undetectable anti-HIV, aspartate aminotransferase activity
$>70 \mathrm{IU} / \mathrm{l}$, and chronic active hepatitis found on liver biopsy predicted response with $100 \%(12 / 12)$ sensitivity and $80 \%(20 / 25)$ specificity in these patients. All patients who lost hepatitis B surface antigen had had documented hepatitis $B$ virus infection for less than two years.

TABLE V-Pretreatment variables associated with response

\begin{tabular}{lcc}
\hline & Responders & Non-responders \\
\hline No & 12 & 25 \\
No with chronic active hepatitis & 12 & 14 \\
No with chronic persistent & 0 & 11 \\
$\quad$ hepatitis & 0 & 6 \\
$\begin{array}{l}\text { No anti-HIV positive } \\
\text { Mean } \log _{10} \text { aspartate } \\
\text { aminotransferase (SD) }\end{array}$ & $2.03(0.24)$ & $1.80(0.32)$ \\
\hline
\end{tabular}

Anti-interferon antibodies were detected in two responders and one non-responder before but not during treatment, though all denied previous treatment with the drug. Two non-responders had transiently detectable antibodies after one and two months of treatment respectively. One patient who responded to treatment with the loss of hepatitis B surface antigen and hepatitis $\mathrm{B}$ e antigen had antibodies detectable throughout treatment from the first month. In all cases the titres were just at the limit of detection.

$\beta_{2}$ Microglobulin-The 11 responding patients tested had a lower mean $\beta_{2}$ microglobulin concentration initially $(2 \cdot 10(\mathrm{SD} 1 \cdot 17) \mathrm{mg} / \mathrm{l})$ than the 19 nonresponding patients tested $(2 \cdot 48(0.85) \mathrm{mg} / \mathrm{l})$. The mean rise in value after one month of treatment was greater in the responders $(1.77 v 1.27 \mathrm{mg} / \mathrm{l})$ but in neither case was this significant.

Adverse effects - Thirty four of the 37 treated patients injected the drug satisfactorily. Over the first week patients experienced flu-like symptoms, graded severe in four. The side effects reported during the subsequent 11 weeks of treatment and scored as severe were fatigue (five patients), gastrointestinal disturbance (five), anorexia (two), depression (one), myalgia (one), and hair loss (one). Fever was also reported but was never troublesome. These severe side effects occurred in 11 patients. Twelve treated patients had a weight loss of more than $5 \%$ of their pretreatment weight. Only two patients stated that further interferon would be unacceptable.

Dose reductions and withdrawals-Fourteen patients had the dose of interferon alfa reduced from the 365 $\mathrm{MU} / \mathrm{m}^{2}$ in the protocol to between 162.5 and $350 \mathrm{MU} /$ $\mathrm{m}^{2}$. In 10 this was because of neutropenia, in three because of thrombocytopenia, and in one because of depression. Six of these patients were treatment responders. Four of the 34 controls were lost to follow up after less than six months of observation, at which time all were positive for hepatitis $\mathrm{B}$ e antigen and hepatitis B virus DNA. They were excluded from analysis of the main outcome measures in order to avoid underestimation of the rate of natural seroconversion. The data on all 37 treated patients were included in the analysis, though five failed to complete follow up. Three anti-HIV positive patients withdrew because of Kaposi's sarcoma (after seven weeks of treatment), salmonella bacteraemia (after 12 weeks), and liver failure associated with a second HIV related pathogen (eight months after treatment) respectively. Two other patients withdrew two months (moved abroad) and four months after treatment (reason unknown).

Effect of treatment on HIV-One of the four treated anti-HIV positive patients who were tested was positive for HIV p24 antigen before treatment. He became negative for this marker during treatment but was found to be positive again one month after the last dose (fig 2). He died of an HIV related cause eight months 
after treatment. The other three patients had anti-p24 antibody detected in the serum the titres of which were unaffected by treatment.

Liver biopsies-Table II gives the histological findings before treatment in all patients. Thirteen treated and 17 untreated patients agreed to a second biopsy at the end of follow up (table VI). One responder showed decreased hepatic inflammation and one showed no change. In nine non-responders the findings of the second biopsy were unchanged and deterioration was found in two. Three untreated controls showed deterioration at the second biopsy (two developing cirrhosis), 11 showed no change, and three had improved.

\section{Discussion}

This large, randomised controlled trial confirms the results of smaller studies 121316 that interferon alfa is a safe and effective treatment of chronic hepatitis B virus infection, inducing persistent loss of hepatitis B e antigen and hepatitis B virus DNA in $32 \%$ of all patients and $39 \%$ of anti-HIV negative patients. Of additional interest in our series was the loss of HIV p24 antigen in one patient during treatment, suggesting that interferon alfa has a direct action against HIV in vivo.

None of the anti-HIV positive patients responded. It might be argued that the mild hepatitis usually seen in anti-HIV positive carriers of hepatitis $B$ virus ${ }^{17-14}$ makes their treatment less imperative. One anti-HIV positive control, however, developed cirrhosis during the trial period. There is also evidence that carriage of hepatitis B virus adversely affects the course of HIV infection. ${ }^{20.1}$ Alternative treatment strategies are therefore required for these patients, such as more prolonged courses of interferon or combinations also including drugs such as zidovudine."

Response could be predicted retrospectively by a combination of the pretreatment variables chronic active hepatitis, negative anti-HIV state, and serum aspartate aminotransferase activity $>70 \mathrm{IU} / \mathrm{l}$, indicating that such patients are already making an incomplete attempt at immune clearance of infected hepato-

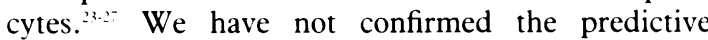
relevance of hepatitis B virus DNA concentration or sexual preference that has been found in other

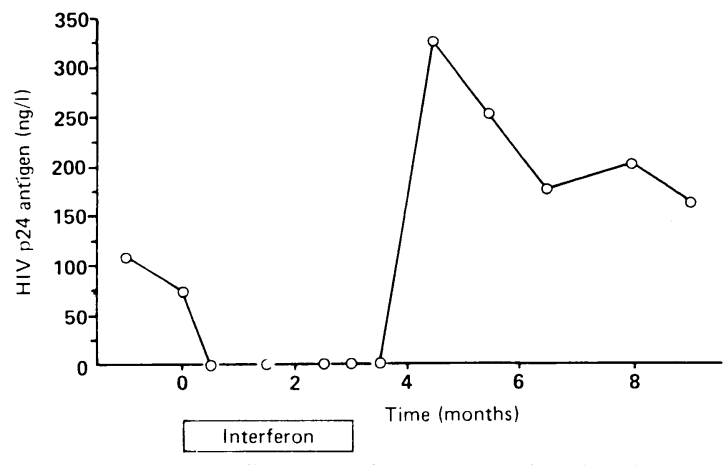

FIG 2-Course of $\mathrm{HII}^{r}$ p24 antigen concentrations in relation to treatment in one patient

TABLE VI -Evolution of histological picture in patients agreeing to two liver biopsies

\begin{tabular}{|c|c|c|c|c|}
\hline Study group & Before treatment & No of patients & End of follow up & No of patients \\
\hline Responders & Chronic active hepatitis & 2 & $\left\{\begin{array}{l}\text { Chronic active hepatitis } \\
\text { Chronic persistent hepatitis }\end{array}\right.$ & $\begin{array}{l}1 \\
1\end{array}$ \\
\hline Non-responders & $\left\{\begin{array}{l}\text { Chronic active hepatitis } \\
\text { Chronic persistent hepatitis }\end{array}\right.$ & $\begin{array}{l}6 \\
5\end{array}$ & $\begin{array}{l}\text { Chronic active hepatitis } \\
\text { /Chronic active hepatitis } \\
\text { |Chronic persistent hepatitis }\end{array}$ & $\begin{array}{l}6 \\
2 \\
3\end{array}$ \\
\hline Controls & $\left\{\begin{array}{l}\text { Chronic active hepatitis } \\
\text { Chronic persistent hepatitis }\end{array}\right.$ & $\begin{array}{l}14 \\
3\end{array}$ & $\begin{array}{l}\left\{\begin{array}{l}\text { Chronic active hepatitis } \\
\text { Chronic persistent hepatitis } \\
\text { Active cirrhosis }\end{array}\right. \\
\text { Chronic active hepatitis } \\
\text { Chronic persistent hepatitis }\end{array}$ & $\begin{array}{l}9 \\
3 \\
2 \\
1 \\
2\end{array}$ \\
\hline
\end{tabular}

trials ${ }^{11-13162 \times 29}$; these associations, however, may be idiosyncratic to this group of patients.

A further factor which might have but did not influence response was the development of neutralising anti-interferon antibodies. These have been shown to reduce the effects of recombinant alfa interferon, especially when given for six months or more in the treatment of hairy cell leukaemia and chronic myeloid leukaemia. ${ }^{313}$ They were detected in low titres in only three patients during treatment in this trial. Even in the presence of antibodies induced by recombinant alfa interferon, leucocyte interferon has been shown to be an effective therapeutic agent. ${ }^{30}$ These observations may be explained by the fact that leucocyte and lymphoblastoid interferons are mixtures of at least 16 different alfa interferons, ${ }^{32}$ with such antibodies having specificity against only one or some of these.

The non-responders probably required a larger boost to their immunity than our regimen provided. ${ }^{33} .34$ Withdrawal of steriods followed by interferon alfa shows such promise. Nevertheless, though Perrillo et al have recently reported that two anti-HIV positive patients responded to withdrawal of prednisone followed by interferon alfa,${ }^{35}$ the overall proportion of patients losing hepatitis B e antigen and hepatitis B virus DNA was $44 \%$ and the loss occurred entirely in patients with chronic active hepatitis, in whom we observed a response rate of $46 \%(12 / 26)$ with interferon alfa alone.

Treatment was well tolerated in most cases. The main reasons for a reduction in dose were neutropenia or thrombocytopenia, which were rapidly corrected once the dose was reduced. There is therefore every reason to believe that interferon alfa may successfully be used in most hospitals.

In other studies the histological picture of the liver has been seen to improve significantly in responders. ${ }^{36}$ That two untreated controls developed cirrhosis over the course of our study emphasises the need for an early treatment induced response, particularly in patients with chronic active hepatitis. Ways of improving the response rate are now required to bring the benefits of treatment, including the possible avoidance of cirrhosis and hepatocellular carcinoma, to a larger proportion of patients."

1 Krugman S, Overby LR, Mushawer IK Ling CM, Frosner GG, Deinhardt I. Viral hepatitis type B. Studies on the natural history and prevention reTiral

2 Marnard JE, Kane MA, Alter MJ, Hadler SC. Control of hepatitis B by immunisation: global perspectives. In: Zuckerman AJ, ed. V'iral hepatitis and liver liseus Nork: Alan R Liss, 1988:967-9.

3 Lo $K$-J. Tsu Y-T, Lece S-D, el al. Immunoprophylaxis of infection with hepatitis $B$ virus in infants born to hepatitis $B$ surface antigen positive carrie mothers. F Infect Dis 1985;152:817-22.

+ Beasley RP, Lin C-C, Wan K-Y, $c t$ al. Hepatitis B immune globulin $(\mathrm{HBIg}$ fficacy in the interruption of perinatal transmission of the hepatitis $B$ carrie state. Luncet 1981:ii:388-93

Sherlock S, ed. Viral hepatis. In: Dise'ase's of the liver and biliary sustem. Oxford: Blackwell Scientific, 1985.251-99.

6 Beasley RP, I in C-C, Hwang L-Y. Chien C-S. Hepatocellular carcinoma an hepatitis B virus. Lancet 1981:ii:1129-33.

Hall Af Winter PD, Wrighe $R$. Mortality of hepatitis B posirive blood donors. Lancet 1985;: :91-3.

8 Beaser. RP, Lee C-Y, Roan C-H, ct al. Prevention of perinatally transmitted hepatitis $B$ virus infection with hepatitis $B$ immune globulin and hepatitis $B$ raccine Lance 1983;ii:1099-102.

9 Lai C-L, Lin H-J, Yeoh E-K, Lok ASF, Wu P-C, Yeung (i-Y. Placebo controlled trial of recombinant ${ }^{2} 2$-interferon in Chinese HBsAg carrie hildren. Lancet 1987;ii:877-80.

10 Omata M. Imazeki F, Yokosuha O. Recombinant leucocyte interferon treatment in patients with chronic hepatitis B virus infection. (jastroenterolog 1985:88:870-80

1 Doolev JS, Davis GL, Peters $\mathrm{M}$, W'aggoner JG, Goodman $Z$, Hoofnagle JH. Pilot study of recombinant human alfa interferon for chronic type B hepatitis. (justroenterologv 1986;90:150-7.

12 Alexander (iM, Brahm J, Fagan EA, et al. Loss of HBsAg with interferon theraps in chronic hepatitis B virus infection. Lancet 1987; ;i:66-9.

13 Scull: LJ. Sheen R, Karaviannis P, McDonald JA, Thomas HC. Lymphoblastoid interferon therapy of chronic HBV infection. A comparison of 12 blastoid interferon therapy of chronic HBV infection. A comparis
versus $2+$ weeks of thrice weckly treatment. F Hepatol 1987;5:51-8.

It Goodall AH, Meck FL, Waters JA. Miescher GC. Jannoss G, Thomas HC. A rapid one step radiometric assav for hepatitis $\mathrm{B}$ surface antigen utilising rapid one step radiometric assay for hepatitis $B$ surface antig

15 Weller IVD, Fowler MJ. Monjardino J. Thomas HC. The detection of HBV DNA in serum by molecular hybridisation; a more sensitive method for the detection of complete HBV particles. F. Med Virol 1982:9:273-80. 
16 Lok ASF, Novick DM, Karaviannis P, Dunk A, Sherleck S, Themas HC. A randomised study of the effects of adenine arabinoside 5'monophosphat (short or long courses) and lymphoblastoid interferon in hepatitis B viru infection. Heputologv 1985;5:1132-8.

17 Caruso L, Weher J, Forster G, et al. Effects of HTLV III virus infection of $\mathrm{HBV}$ replication, severity of liver disease and response to interferon treatment in chronic hepatitis B virus carriers. $f$ Héputol 1986;3 (suppl 2):207.

18 McDonald JA, Harris S, Waters JA, Thomas HC. Effect of human immunodeficiency virus (HIV) infection in chronic hepatitis B viral antigen display. $\mathcal{J}$ Heputol 1987;4:337-42

19 Krogsgard K, Lindhart OB, Nielson JO, et al. The influence of HTLV-III infection on the natural history of hepatitis $B$ virus infection in male infection on the natural history of hepatitis B virus
homosexual HBsAg carriers. Hepatology 1987;7:37-41.

20 Noonan CA, Yoffe B, Mansell PW, Melnick JL, Hollenger FB. Extrachromosomal sequences of hepatitis B virus DNA in peripheral bloed mononuclear cells of acquired immunodeficiency syndrome patients. Proc Nall Acad Sc USA 1986;83:698-702.

21 Hirschman SZ, Zucker ML. Recombinant DNA related to hepatitis B and human immunodeficiency viruses in mononuclear cells of patients with AIDS. F Med Virol 1988;26:145-52

22 Fischl MA, Richman DD, Grieco MH, et al. The efficacy of azidothrmidine (AZT) in the treatment of patients with AIDS and AIDS-related complex. $N$ Engl I Med 1987;317:192-7.

23 Vento S, Hegarty JE, Alberti A, et al. T lymphocyte sensitisation to $\mathrm{HBCAg}$ and $\mathrm{T}$-cell mediated unresponsiveness to $\mathrm{HBsAg}$ in hepatitis $\mathrm{B}$ virus related chronic liver disease. Hepatology 1985;5:192-7.

24 Hegarty JE, Fagan E, Johnson P. Immunological responses in liver disease. Liver Annual 1985:4:209-38.

25 Waters JA, Pignatelli $M$, Brown D, et al. The immune response to hepatitis $\mathrm{B}$ virus. Postgrad Med f 1987;63 (suppl 2):51-6.

26 Ferrari C, Penna A, Degli-Antoni A, Fiaccodori F. Cellular immune response to hepatitis B virus antigens. $\mathcal{F}$ Hepatol 1988;7:21-3.
27 Pignatelli M, Waters J, Lever A, I warson S, Gerety R, Thomas HC. Cytotoxic T-cell responses to the nucleocapsid proteins of $\mathrm{HBV}$ in chronic hepatitis. $\mathcal{f}$ Hepatol 1987;4:15-21.

28 McDonald JA, Caruso L, Karayiannis P, et al. Diminished responsiveness of male homosexual carriers with HTLV-III antibodies to recombinant alfa interferon. Heputology 1987;3:719-23.

29 Novick DM, Lok ASF, Thomas HC. Diminished responsiveness of homosexual men to antiviral therapy for $\mathrm{HBsAg}$ positive chronic liver disease. $\mathcal{f}$ Hepatol 1985; 1:29-35.

30 Von Wussow P, Hartman F, Freund M, Poliwoda H, Deicher H. Leucocyte derived interferon alpha in patients with antibodies to recombinant IFNderived interferon alpha in

31 Steers RG, Smith JW, Urba WJ, et al. Resistance to recombinant interferon alfa $2 \mathrm{a}$ in hairy cell leukemia associated with neutralising anti-interferon antibodies. $N$ Engl $\mathcal{F}$ Med 1988;318:1409-13.

32 Finter NB. The classification and biological functions of the interferons. $f$ Hepatol 1986;3(suppl 2):S157-60.

33 Billau $A$. The mode of action of interferons in viral infections and their possible role in the control of hepatitis B. F Hepatol 1986;3(suppl 2):S171-9.

3t Morris A, Cooley $M$, Blackman $M$. The interaction of interferon with th immune response. f Heputol 1986;3(suppl 2):S161-9.

35 Perrillo RP, Regenstein FG, Peters MG, et al. Prednisone withdrawal followed by recombinant alfa interferon in the treatment of chronic type $B$ hepatitis. Ann Intem Med 1988;109:95-100.

36 Brook MG, Petrovic L, McDonald JA, Scheuer PJ, Thomas HC. Histological improvement after antiviral treatment for chronic hepatitis B virus infection. f Heputol 1989:8:218-25.

37 Scullard GH, Andres LL, Greenterg HB, et al. Antiviral treatment of chronic hepatitis $B$ virus infection: improvement in liver disease with interferon and adenine arabinoside. Heputology 1981;1:228-32.

(Accepted 21 fuly 1989)

\section{Post-transfusion hepatitis in Trent Regional Health Authority, 1988}

\section{P Flanagan, P Nuttall, V James}

Trent Regional Blood

Transfusion Centre,

Sheffield S5 7JN

P Flanagan, MRCPATH, senior

registrar

P Nuttall, SRMLT, head of

microbiology

V James, FRCPATH,

consultant haematologist

Correspondence to:

Dr Flanagan.

BrMed f 1989;299:656-7
Post-transfusion hepatitis still occurs in the United Kingdom despite the introduction of sensitive assays for hepatitis B surface antigen. Only a small proportion of cases of hepatitis transmitted by transfusion is recognised by doctors and reported to regional transfusion centres. ${ }^{\prime}$ Furthermore, non-A, non-B hepatitis is the predominant type transmitted by transfusion and probably accounts for more than $90 \%$ of cases. ${ }^{2}$ We studied all cases of suspected post-transfusion hepatitis reported to this centre in one year and investigated the donors in these cases for markers of hepatitis infection.

\section{Subjects, methods, and results}

During 1988 six cases of suspected post-transfusion hepatitis were reported to this centre; five were cases of hepatitis B and one of non-A, non-B hepatitis. Three of

Results of serological testing for markers of hepatitis infection in donors who had donated blood given to six patients who developed hepatitis $B$ or non- $A$, non- $B$ hepatitis

\begin{tabular}{|c|c|c|c|c|c|c|}
\hline \multirow[b]{2}{*}{$\begin{array}{l}\text { Case } \\
\text { No }\end{array}$} & \multirow[b]{2}{*}{$\begin{array}{c}\text { Type } \\
\text { of } \\
\text { hepatitis }\end{array}$} & \multirow[b]{2}{*}{$\begin{array}{c}\text { No } \\
\text { of } \\
\text { donors }\end{array}$} & \multicolumn{3}{|c|}{ Results of serological testing of donors for: } & \multirow[b]{2}{*}{$\begin{array}{c}\text { History of } \\
\text { hepatitis } \\
\text { in donors }\end{array}$} \\
\hline & & & $\begin{array}{c}\text { Hepatitis B } \\
\text { surface } \\
\text { antigen }\end{array}$ & $\begin{array}{c}\text { Hepatitis B } \\
\text { core } \\
\text { antibody }\end{array}$ & $\begin{array}{c}\text { Hepatitis B } \\
\text { surface } \\
\text { antibody }\end{array}$ & \\
\hline \multicolumn{7}{|c|}{ Hepatitis not transmitted by transfusion } \\
\hline $\begin{array}{l}1 \\
2 \\
3\end{array}$ & $\begin{array}{l}\text { B } \\
\text { B } \\
\text { B }\end{array}$ & $\begin{array}{l}4 \\
1 \\
2\end{array}$ & $\begin{array}{l}3 \text { Negative, 1 ND } \\
\text { Negative } \\
2 \text { Negative }\end{array}$ & $\begin{array}{l}2 \text { Negative, } 2 \mathrm{ND} \\
\text { Negative } \\
2 \text { Negative }\end{array}$ & $\begin{array}{l}\text { ND } \\
\text { ND } \\
\text { ND }\end{array}$ & $\begin{array}{l}\text { No } \\
\text { No } \\
\text { No }\end{array}$ \\
\hline \multicolumn{7}{|c|}{ Hepatitis probably transmitted by transfusion } \\
\hline 4 & B & 4 & 4 Negative & $\left\{\begin{array}{l}3 \text { Negative } \\
1 \text { Positive }\end{array}\right.$ & $\begin{array}{l}\text { ND } \\
\text { Negative* }\end{array}$ & $\begin{array}{l}\text { No } \\
\text { Yes }\end{array}$ \\
\hline 5 & B & 4 & 4 Negative & $\left\{\begin{array}{l}3 \text { Negative } \\
1 \text { Positive }\end{array}\right.$ & $\begin{array}{l}\text { ND } \\
\text { Negative* }\end{array}$ & $\begin{array}{l}\text { No } \\
\text { Yes }\end{array}$ \\
\hline 6 & Non- $A$, non-B & 2 & 2 Negative & $\left\{\begin{array}{l}1 \text { Negative } \\
1 \text { Positive }\end{array}\right.$ & $\begin{array}{l}\text { ND } \\
\text { Weakly positive }\end{array}$ & $\begin{array}{l}\text { No } \\
\text { No }\end{array}$ \\
\hline
\end{tabular}

$\mathrm{ND}=$ Not done

${ }^{\star}$ Result negative by haemagglutination test but low levels of antibody detected by radioimmunoassay. the cases of hepatitis B infection formed a cluster in one hospital in the region, and investigations performed by the Public Health Laboratory Service yielded a common source of infection not related to blood transfusion. These three cases were therefore not due to transfusion. The infection in the other three cases seemed to have been transmitted by transfusion.

The donors implicated in all six episodes were contacted and samples obtained for testing for markers of hepatitis B infection. Samples were obtained from 16 of the 17 donors either in response to postal contact or after redonation; one donor (case 1) did not respond to postal contact. The table gives the results. Hepatitis B surface antibody was sought only in donors positive for hepatitis B core antibody. In addition, alanine aminotransferase activity was measured in the two donors who might have transmitted non- $A$, non-B hepatitis infection; it was within the normal range in both.

In each of the three cases of disease probably related to transfusion one donor was shown to be positive for hepatitis B core antibody. Furthermore, in the two cases of hepatitis B probably related to transfusion the donors positive for hepatitis B core antibody gave histories of acute hepatitis two to three years before donation.

\section{Comment}

Transmission of hepatitis B by transfusion of blood negative for hepatitis $B$ surface antigen but positive for hepatitis B core antibody has been reported. ${ }^{3}$ Donors who are negative for hepatitis $B$ surface antibody have been shown to confer the greatest risk, but there is circumstantial evidence of transmission of hepatitis B by donors with both hepatitis B core antibody and low levels of hepatitis B surface antibody. ${ }^{+}$Screening for hepatitis B core antibody and measurement of alanine aminotransferase activity are used in many countries to determine whether a subject may be a carrier of non-A, non-B hepatitis. ${ }^{2}$ In the United Kingdom testing for hepatitis B core antibody is currently recommended only as follow up in cases of suspected post-transfusion hepatitis.

Although the number of cases we have reported is small, our findings are interesting as, firstly, in both cases of hepatitis B infection transmitted by transfusion a donor was positive for hepatitis B core antibody and 